\title{
Korelasi Antara Profil Hematologi Dengan Procalcitonin Pada Pasien Terkonfirmasi Covid-19
}

\author{
Puspitasari $^{1}$, Andika Aliviameita ${ }^{1}$, Evi Rinata ${ }^{1}$, Dira Nadila ${ }^{1}$ \\ 1) Universitas Muhammadiyah Sidoarjo \\ Correspondence to: puspitasari@umsida.ac.id
}

\begin{abstract}
Tanggal Submit:

27 Januari 2021

Tanggal Review:

22 Februari 2021

Tanggal Publish

Online: 18 Juni 2021

Covid-19 is an infectious disease caused by SARS-CoV 2 and has spread very quickly. Several laboratory examinations were carried out on Covid-19 patients including molecular examinations, hematological profiles, and serology. This study aims to determine the relationship between leucocyte, d-dimer, hemoglobin and thrombocyte against procalcitonin in patients with Covid-19. This study was an observational analytic with cross sectional design. A sample of 50 was taken at Aisyiyah Siti Fatimah Tulangan Hospital in November 2020 January 2021. The result of multiple linear regression test showed relationship between leucocyte with procalcitonin $(\mathrm{b}=-0.64 ; \mathrm{p}=$ $0.426)$, d-dimer with procalcitonin $(b=2.702 ; p=0.010)$, hemoglobin with procalcitonin $(b=0.656 ; p=0.255)$, and thrombocyte with procalcitonin $(b=0.037 ; p=0.002)$. Based on the results, it is found that there is relationship between leucocyte, d-dimer, hemoglobin, and thrombocyte againts procalcitonin in Covid-19 patients.
\end{abstract}

Keywords : Covid-19, Procalcitonin, Leukosit, D-dimer, Hemoglobin, Trombosit

\section{PENDAHULUAN}

Pada bulan Desember 2019, Indonesia merupakan salah satu pandemi penyakit Coronavirus yang negara yang juga terkena dampak bermula di Wuhan Cina sangat cepat menyebar luas ke seluruh dunia. Sampai dengan 31 Juli 2020, tercatat sebesar 17.106.007 kasus global dengan angka kematian sebesar 668.910 kasus. Covid19 tersebar di berbagai negara seperti Asia Tenggara, Australia, Timur Tengah, Eropa, Amerika Utara, dan Covid-19. Pada awal bulan Agustus 2020 terdapat 4,68\% kasus. Coronavirus Disease 2019 (COVID-19) merupakan penyakit infeksi yang disebabkan oleh SARS-CoV 2. SARS-CoV 2 memiliki karakteristik menyerupai virus SARS (Grace, 2020). Berdasarkan data Badan

Nasional Penanganan Bencana Di lainnya (Priscilia et al, 2020).

Indonesia pada 26 April 2020, pasien

Covid-19 berjumlah 8.882 penderita dan 
meninggal sebanyak 743 penderita (BNPB, 2020).

Pada 18 Juni 2020 dilaporkan terjadi peningkatan tambahan kasus baru setiap hari dari rata-rata 1.0001.100 menjadi 1.331 kasus. Penambahan tertinggi terjadi di Jawa Timur sebanyak 384 kasus (Amalia dan Hairunisa, 2020).

Kasus Covid-19 yang berat didapatkan terjadi peningkatan jumlah leukosit dan rasio neutrofil-limfosit, penurunan jumlah limfosit, serta penurunan persentase monosit, eosinofil, dan basofil (Susilo et al, 2020).

Pemeriksaan penunjang

laboratorium antara lain seperti pemeriksaan hematologi, tes faal ginjal, analisis gas darah, hemostasis, laktat, procalcitonin dan kadar D-dimer. Kadang dijumpai pula kondisi trombositopenia, sehingga diduga sebagai pasien dengue (Susilo et al, 2020).

Hasil laboratorium ditemukan peningkatan D-dimer dan penurunan angka limfosit apabila terdapat gejala seperti cedera otot rangka (Kurnianto et al, 2020).

Procalcitonin (PCT) merupakan salah satu indikator yang penting untuk melihat keparahan reaksi inflamasi terhadap infeksi mikroba. Kadar procalsitonin dapat mengalami peningkatan pada kasus infeksi yang disebabkan oleh bakteri, sedangkan apabila infeksi disebabkan oleh virus maka kadarnya tetap normal (Suhaymi et al., 2016).

Berdasarkan latar belakang diatas maka dilakukan penelitian yang bertujuan untuk mengetahui hubungan antara jumlah leukosit, d-dimer, hemoglobin, dan trombosit dengan procalcitonin pada pasien terkonfirmasi Covid-19.

\section{METODE PENELITIAN}

Jenis penelitian ini adalah analitik observasional dengan desain cross sectional. Penelitian dilakukan di Rumah Sakit Aisyiyah Siti Fatimah Tulangan Sidoarjo pada bulan November 2020 sampai Januari 2021. Sebanyak 50 sampel digunakan dalam penelitian ini dan diambil secara selektif sampling. Jenis data yang digunakan adalah data sekunder hasil pemeriksaan procalcitonin, jumlah leukosit, D-dimer, hemoglobin, dan jumlah trombositpada pasien terkonfirmasi Covid-19. Data yang didapatkan selanjutnya dianalisis dengan uji statistik regresi linier berganda menggunkan program SPSS versi 22.

\section{HASIL PENELITIAN}

Subyek dalam penelitian ini yaitu pasien terkonfirmasi Covid 19 sebanyak 50 orang. Karakteristik subjek penelitian dianalisis berdasarkan umur dan jenis 
kelamin. Tabel 1 menunjukkan bahwa dari 50 subjek penelitian didapatkan 6,0\% pasien terkonfirmasi Covid-19 berumur 0 sampai 5 tahun (balita), 4,0\% berumur 12 sampai 25 tahun (remaja),
$26,0 \%$ berumur 26 sampai 45 tahun (dewasa), 56,0\% berumur 46-65 tahun (lansia), dan $8 \%$ berumur $>65$ tahun (manula); jenis kelamin laki-laki sebesar $42,0 \%$ dan perempuan sebesar $58,0 \%$.

TABEL 1. Karakteristik Subyek Penelitian

\begin{tabular}{llcc}
\hline Karakteristik & \multicolumn{1}{c}{ Kriteria } & $\mathbf{n}$ & $\mathbf{\%}$ \\
\hline Umur & $0-5$ tahun & 3 & 6,0 \\
& 12-25 tahun & 2 & 4,0 \\
& $26-45$ tahun & 13 & 26,0 \\
& $46-65$ tahun & 28 & 56,0 \\
& $>65$ tahun & 4 & 8,0 \\
Jenis Kelamin & Laki-laki & 21 & 42,0 \\
& Perempuan & 29 & 58,0 \\
Procalcitonin & $<0,5(\mathrm{ng} / \mathrm{mL})$ & 36 & 72,0 \\
& $\geq 0,5(\mathrm{ng} / \mathrm{mL})$ & 14 & 28,0 \\
Leukosit & $<4,0\left(10^{3} / \mu \mathrm{L}\right)$ & 2 & 4,0 \\
& $4,0-10,0$ & 38 & 76,0 \\
& $\left(10^{3} / \mu \mathrm{L}\right)$ & & \\
D-dimer & $>10,0\left(10^{3} / \mu \mathrm{L}\right)$ & 10 & 20,0 \\
& $<0,5(\mathrm{mg} / \mathrm{L})$ & 27 & 54,0 \\
Hemoglobin & $\geq 0,5(\mathrm{mg} / \mathrm{L})$ & 23 & 46,0 \\
& $<12 \mathrm{~g} / \mathrm{dL}$ & 11 & 22,0 \\
& $12-16 \mathrm{~g} / \mathrm{dL}$ & 36 & 72,0 \\
Trombosit & $>16 \mathrm{~g} / \mathrm{dL}$ & 3 & 6,0 \\
& $<150\left(10^{3} / \mu \mathrm{L}\right)$ & 4 & 8,0 \\
& $150-350$ & 36 & 72,0 \\
& $\left(10^{3} / \mu \mathrm{L}\right)$ & & \\
& $>350\left(10^{3} / \mu \mathrm{L}\right)$ & 10 & 20,0 \\
\hline
\end{tabular}

$54,0 \%$ pasien

Pasien terkonfirmsi Covid-19 yang memiliki kadar Procalcitonin $<0,5$ $\mathrm{ng} / \mathrm{mL}$ yaitu sebesar $72,0 \%$, sedangkan dengan procalcitonin $\geq 0,5 \mathrm{ng} / \mathrm{mL}$ sebesar $28,0 \%$. Jumlah leukosit pada pasien terkonfirmasi Covid-19 yang normal yaitu 4,0-10,0 $\left(10^{3} / \mu \mathrm{L}\right)$ sebanyak $76,0 \%$, sedangkan pasien Covid -19 dengan jumlah leukosit rendah $<4,0$ $\left(10^{3} / \mu \mathrm{L}\right)$ sebanyak $4,0 \%$ dan dengan jumlah leukosit tinggi $>10,0\left(10^{3} / \mu \mathrm{L}\right)$ sebanyak $20,0 \%$. terkonfirmasi Covid-19 dengan kadar DDimer $<0,5 \mathrm{mg} / \mathrm{L}$ dan $46,0 \%$ memiliki kadar D-Dimer $\geq 0,5 \mathrm{mg} / \mathrm{L}$. Pada hasil pemeriksaan hemoglobin menunjukkan terdapat $22,0 \%$ pasien terkonfirmasi Covid-19 dengan kadar hemoglobin rendah yaitu $<12 \mathrm{~g} / \mathrm{dL}, 72,0 \%$ pasien dengan kadar hemoglobin normal yaitu $12,0-16,0 \mathrm{~g} / \mathrm{dL}$, dan terdapat $6,0 \%$ pasien dengan kadar hemoglobin tinggi yaitu $>16,0 \mathrm{~g} / \mathrm{dL}$.

Tabel 1 juga menunjukkan jumlah trombosit pada pasien 
terkonfirmasi Covid-19 yang normal yaitu $150-350\left(10^{3} / \mu \mathrm{L}\right)$ sebanyak $72 \%$, dibawah nilai normal $<150 \quad\left(10^{3} / \mu \mathrm{L}\right)$ sebanyak $8,0 \%$ dan diatas nilai normal $>350\left(10^{3} / \mu \mathrm{L}\right)$ sebanyak $20 \%$ pasien.

Tabel 2 menunjukkan Koefisien regresi antara jumlah leukosit dengan kadar procalcitonin memiliki nilai negatif 0,64 dengan nilai $\mathrm{p}=0,426$.
Penurunan kadar leukosit sebesar 1 $\left(10^{3} / \mu \mathrm{L}\right)$ dapat meningkatan kadar procalcitonin pada pasien terkonfirmasi Covid-19 sebesar 0,64 ng/mL. Koefisien regresi antara d-dimer dengan procalcitonin memiliki nilai positif 2,702 dengan nilai $\mathrm{p}=0,010$ dan dinyatakan signifikan secara statistik.

\begin{tabular}{cccc}
\multicolumn{4}{c}{ TABEL 2. Analisis Regresi Linier Berganda } \\
\cline { 2 - 4 } $\begin{array}{c}\text { Variabel } \\
\text { Independen }\end{array}$ & $\mathbf{b}$ & $\mathbf{t}$ & $\mathbf{p}$ \\
hitung & \\
\hline $\begin{array}{c}\text { Leukosit }\left(10^{3} / \mu \mathrm{L}\right) \\
\text { D-Dimer }(\mathrm{mg} / \mathrm{L}) \\
\text { Hemoglobin } \\
(\mathrm{g} / \mathrm{dL})\end{array}$ & $-0,64$ & $-0,804$ & 0,426 \\
Trombosit & 0,656 & 1,153 & 0,255 \\
$\left(10^{3} / \mu \mathrm{L}\right)$ & 0,037 & 3,380 & 0,002 \\
$\mathrm{t}$ tabel & & $=1,679$ \\
$\mathrm{R}$ & & $=0,658$ \\
R-square & $=0,433$ \\
Adj. R-square & $=0,382$ \\
F hitung & $=8,578$ \\
Sig. F & $=0,000$ \\
F tabel & $=2,580$ \\
\hline
\end{tabular}

Peningkatan kadar d-dimer sebesar $1 \mathrm{mg} / \mathrm{L}$ dapat meningkatan kadar procalcitonin sebesar $2,702 \mathrm{ng} / \mathrm{mL}$. Koefisien regresi antara hemoglobin dengan procalcitonin memiliki nilai positif 0,656 dengan nilai $\mathrm{p}=0,255$. Peningkatan kadar hemoglobin sebesar 1 $\mathrm{g} / \mathrm{dL}$ dapat meningkatan kadar procalcitonin sebesar $0,656 \mathrm{ng} / \mathrm{mL}$. Nilai koefisien regresi antara jumlah trombosit dengan procalcitonin bernilai positif 0,037 dengan nilai $\mathrm{p}=0,002$ dan secara statistik dinyatakan signifikan. Peningkatan jumlah trombosit sebesar 1 $\left(10^{3} / \mu \mathrm{L}\right)$ dapat meningkatan kadar procalcitonin sebesar $0,037 \mathrm{ng} / \mathrm{mL}$. Berdasarkan tabel 2 diketahui nilai RSquare yaitu sebesar 0,433 atau 43,3\%. Artinya kadar procalcitonin dipengaruhi oleh variabel jumlah leukosit, kadar ddimer, hemoglobin, dan jumlah trombosit dengan presentase sebesar $43,3 \%$, sedangkan $56,7 \%$ dipengaruhi oleh faktor lainnya yang tidak masuk dalam penelitian.

Jumlah leukosit, kadar d-dimer, hemoglobin, dan jumlah trombosit berpengaruh secara simultan terhadap kadar procalcitonin pada pasien 
terkonfirmasi Covid-19. Hal ini terbukti dengan hasil uji statistik yaitu nilai $F$ hitung sebesar 8,578 (sig $\mathrm{F}=0,000$ ), sehingga dapat dilihat $\mathrm{F}$ hitung $>\mathrm{F}$ tabel $(8,578>2,580)$. Tabel 2 menunjukkan terdapat hubungan antara leukosit dengan procalcitonin. Hal ini ditunjukkan dari hasil statistik yaitu nilai t hitung untuk variabel jumlah leukosit sebesar $0,804(\mathrm{p}=0,426)$, sehingga $\mathrm{t}$ hitung > $\mathrm{t}$ tabel $(0,804>1,679)$, akan tetapi nilai $\mathrm{t}$ memiliki nilai negatif yang artinya terdapat hubungan yang berlawanan antara jumlah leukosit dengan kadar procalcitonin.

$$
\text { Kadar d-dimer juga }
$$

menunjukkan adanya hubungan dengan procalcitonin yang terlihat dari hasil $\mathrm{t}$ hitung yaitu sebesar 2,704 ( $\mathrm{p}=0,010)$, sehingga $\mathrm{t}$ hitung $>\mathrm{t}$ tabel $(2,704>1,679)$, dan nilai t memiliki nilai positif yang artinya terdapat hubungan yang positif antara kadar d-dimer dengan procalcitonin pada pasien terkonfirmasi Covid-19. Sedangkan untuk kadar hemoglobin menunjukkan tidak berhubungan dengan procalcitonin yang terlihat dari nilai t hitung untuk variabel hemoglobin sebesar 1,153 $(\mathrm{p}=0,255)$, sehingga $\mathrm{t}$ hitung $<\mathrm{t}$ tabel $(1,153<1,679)$. Pada parameter pemeriksaan jumlah trombosit menunjukkan terdapat hubungan dengan procalcitonin yang ditunjukkan dari nilai t hitung yaitu sebesar 3,380 ( $\mathrm{p}=0,002)$, sehingga $\mathrm{t}$ hitung $>\mathrm{t}$ tabel $(3,380>1,679)$, dan nilai t bernilai positif yang menunjukkan hubungan yang positif antara jumlah trombosit dengan procalcitonin pada pasien terkonfirmasi Covid-19.

\section{PEMBAHASAN}

Procalcitonin dalam keadaan fisiologi diitemukan dalam kadar yang rendah atau bahkan tidak ada. Procalcitonin dapat meningkat apabila terjadi infeksi yang disebabkan oleh bakteri dan fungi dan peningkatannya sesuai dengan berat infeksi yang terjadi. Selama terjadi infeksi sitemik, endotoksin yang dihasilkan oleh bakteri akan menginduksi procalcitonin. Terdapat beberapa infeksi yang tidak menginduksi procalcitonin diantaranya yaitu infeksi yang disebabkan oleh protozoa, virus, dan juga penyakit autoimun (Buchori dan Prihantini, 2006).

Pengukuran procalcitonin secara rutin dapat digunakan untuk memonitor perjalanan suatu penyakit dan juga sebagai monitoring dari terapi pada infeksi yang disebabkan oleh bakteri. Peningkatan procalcitonin atau nilai yang tetap tinggi menunjukkan aktifitas dari penyakit yang berkelanjutan, sedangkan apabila procalcitonin mengalami penurunan menunjukkan reaksi penyembuhan suatu infeksi 
(Dharaniya dkk, 2015). Pengukuran procalcitonin juga dapat digunakan untuk melihat efisiensi penggunaan antibiotik, sehingga pemeriksaan secara rutin dapat digunakan sebagai dasar untuk memulai ataupun menghentikan terapi antibiotik (Boudma et al, 2010)

Jumlah leukosit yang tinggi merupakan salah satu respon dari adanya infeksi akibat stimulus sitokin proinflamasi dan adanya endotoksinemia (Pramana dkk, 2014). Pada kasus pneumonia dijumpai jumlah leukosit tinggi yang berasal dari sepsis (Hoser et $a l$, 2012). Pada penelitian ini didapatkan adanya hubungan yang tidak signifikan antara jumlah leukosit dengan procalcitonin pada pasien terkonfirmasi Covid-19. Hasil ini sesuai dengan penelitian yang dilakukan oleh Dharma dkk (2020) yang menyatakan juga terdapat korelasi yang tidak signifikan antara kadar procalcitonin dengan jumlah leukosit pada pasien sepsis. Akan tetapi, hubungan antara jumlah leukosit dengan procalcitonin pada penelitian ini menunjukkan hubungan yang negatif. Hal ini dikarenakan procalcitonin lebih spesifik untuk penanda infeksi bakteri, sedangkan leukosit akan meningkat apabila terjadi infeksi baik bakteri maupun virus.

Pada pasien terkonfirmasi Covid19 mengalami peningkatan pada kadar D-dimer dan fibrinogen. Hal ini menunjukkan terjadinya gangguan koagulasi pada pasien Covid-19. Kadar D-dimer pada pasien terkonfirmasi Covid-19 yang meninggal lebih tinggi dibandingkan dengan kadar D-dimer pasien yang masih hidup (Minuljo dkk, 2020). Kadar D-dimer berhubungan positif dengan derajat keparahan pasien Covid-19 dan dapat dijadikan sebagai prediktor kematian (Yao et al, 2020). Kadar D-dimer memiliki hubungan dengan procalcitonin dan signifikan secara statistik. Procalcitonin digunakan sebagai penentu keparahan sepsis dan juga sebagai predictor tingkat mortalitas maupun morbiditas. Selama terjadi sepsis, D-dimer juga mengalami peningkatan dan D-dimer juga digunakan sebagai penanda tingkat keparahan sepsis (Naderpour et al, 2019).

Hasil pemeriksaan laboratorium seperti hemoglobin dilaporkan telah mengalami perubahan pada pasien terkonfirmasi Covid-19 (Lipi and Plebani, 2020). Pada kondisi sepsis yang sering ditemukan adalah kondisi anemia dimana terjadi penurunan jumlah eritrosit, hematokrit, dan hemoglobin. Akan tetapi literatur lain menyebutkan bahwa hemoglobin tetap normal pada pasien sepsis, kecuali terjadi hemolisis, maka dapat meyebabkan hemoglobinnya rendah (Pairunan dkk, 2016). 
Pada kasus Covid-19 dijumpai trombositopenia, sedangkan procalcitonin dalam batas normal atau meningkat pada fase lanjut. Terdapat beberapa manifestasi klinis dari Covid19, salah satunya manifestasi klinis pada kulit yang juga dapat mempengaruhi hasil trombosit pada pasien (Prakoeswa, 2020).

\section{KESIMPULAN}

Jumlah leukosit memiliki hubungan yang negatif dengan procalsitonin pada pasien terkonfirmasi Covid-19. Sedangkan D-dimer, hemoglobin, dan jumlah trombosit memiliki hubungan yang positif terhadap procalcitonin pada pasien terkonfirmasi Covid-19 yang dirawat di RS Aisyiyah Siti Fatimah Tulangan Sidoarjo Jawa Timur.

Adapun saran untuk penelitian lebih lanjut yaitu dengan jumlah sampel yang lebih banyak dan dengan parameter lainnya yang belum diteliti.

\section{DAFTAR PUSTAKA}

Amalia, H. Dan Hairunisa, N. 2020. Riview Penyakit Virus Corona Baru 2019 (COVID-19). Jurnal Biomedika dan Kesehatan.

Badan Nasional Penanggulangan Bencana (BNPB). 2020. Situasi COVID-19 Indonesia.
Bouadma, L., Luyt, C.E., Tubach, F., et al. 2010.Use of Procalcitonin to Reduce Patient's Exposure to Antibiotics in Intensive Care Units: A Multicentre Randomised Controlled Trial. Lancet, 375, 463-474.

Buchori, Prihatini. 2006. Diagnosis sepsis menggunakan procalcitonin. Indonesian Journal of Clinical Pathology and Medical Laboratory, 12(3):131137

Dharaniya DD., Lie KC., Sunanto, S. 2015. Peran Procalcitonin Sebagai Penanda Inflamasi Sistemik Pada Sepsis. Jurnal Penyakit Dalam Indonesia, 2 (2); 108-114

Dharma, BDA., Mulyantari, NK., Prabawa, IPY. 2020. Analisis korelasi kadar serum prokalsitonin dengan jumlah leukosit pada penderit dengan kecurigaan sepsis di RSUP Sanglah, Bali, Indonesia. Intisari Sains Medis, 11(1):179-182

Grace, C. 2020. Manifestasi Klinis dan Perjalanan Penyakit pada Pasien Covid-19. Jurnal Majority, 9(1).

Hoser, GA., Skirecki T., Zlotorowicz M., Zielinska-Borkowska U, Kawiak J. 2012. Absolute counts of peripheral blood leukocyte subpopulations in intra abdominal sepsis and pneumonia-derived sepsis:a pilot study. Folia Histochem Cytobiol, 50(1):420-6

Lippi G, Plebani M. 2020. Laboratory abnormalities in patients with COVID-2019 infection. Clin Chem Lab Med;58:1131-1134. 
Minuljo, TT., Anindita, YPC., Seno, HNH., Pemayun, TGD., Sofro, MAU. 2020. Karakteristik dan keluaran pasien Covid-19 dengan D< di RS Umum Pusat Dr. Kariadi (Tinjauan Pasien periode Maret-Juli 2020). Medica Hospitalia, 7(1 A):150-158

Naderpour Z., Momeni M., Vahidi E., Sajavi, J., Saeedi M. 2019. Procalcitonin and D-dimer for Predicting 28 Day Mortality Rate and Sepsis severity based on SOFA Score; a cross sectional Study. Bull Emerg Trauma, 7(4):361-365

Pairunan JN., Runtunuwu AL., Salendu PM. 2016. Hubungan pemeriksaan hitung darah lengkap pada anak dengan sepsis. Jurnal e-Clinic, 4(1);76-81

Prakoeswa, FRS. 2020. Dasamuka Covid-19. Medica Hospitalia, 7(1A);231-240

Pramana, Puguh K, Subanada IB. 2014. Hubungan jumlah leukosit serta kadar C-Reactive Protein dengan derajat keparahan pneumonia pada anak. Jurnal ilmiah kedokteran, 46(22):10
Priscilia F., Iskandar F., Larasati FF., Permanik GF. 2020. Manifestasi Okular Coronavirus Disease 2019 (COVID-19) : Klinis dan Pencegahan.CDK-289, vol 47(8)

Suhaymi, E., Fikri, E., \& Nasution, I. P. (2016). Perbandingan Akurasi Diagnostik Kadar Procalcitonin Dan C-Reactive Protein Pada Pasien Appendisitis Anak Di RSUP H.Adam Malik Medan Dan RSUD Dr. Pirngadi Medan. Cermin Dunia Kedokteran, vol 43 (10):727-731.

Susilo A., Rumende M., Pitoyo CW., Santoso WD., Yulianti M., Herikurniawan., Sinto R., Singh G., Nainggolan L., Nelwan EJ., Chen LK., Widhani A., Wijaya E., Wicaksana B., Maksum M., Annisa F., Jasirwan COM., Yunihastuti E. 2020. Coronavirus Disease 2019: Tinjauan Literatur Terkini Coronavirus Disease 2019: Review of Current Literatures. Jurnal Penyakit Dalam Indonesia, 7(1):45-67

Yao Y, Cao J, Wang Q, Shi Q, Liu K, Luo Z, et al. 2020. D-dimer as a biomarker for disease severity and mortality in COVID-19 patients: a case. control study. $J$ Intensive Care, 8:49 